\title{
Radioactive Source Specification of Bushehr's VVER-1000 Spent Fuels
}

\author{
Mahdi Rezaeian' ${ }^{1}$ and Jamshid Kamali ${ }^{2}$ \\ ${ }^{1}$ Nuclear Science and Technology Research Institute, Tehran 11365-8486, Iran \\ ${ }^{2}$ Amirkabir University of Technology, Tehran 15875-4413, Iran \\ Correspondence should be addressed to Mahdi Rezaeian; mdrezaeian@aeoi.org.ir
}

Received 27 August 2016; Accepted 20 October 2016

Academic Editor: Eugenijus Ušpuras

Copyright (C) 2016 M. Rezaeian and J. Kamali. This is an open access article distributed under the Creative Commons Attribution License, which permits unrestricted use, distribution, and reproduction in any medium, provided the original work is properly cited.

Due to high radioactivity and significant content of medium- and long-lived radionuclides, different operations with spent nuclear fuels (e.g., handling, transportation, and storage) shall be accompanied by suitable radiation protections. On the other hand, determination of radioactive source specification is the initial step for any radiation protection design. In this study, radioactive source specification of the spent fuels of Bushehr nuclear power plant, which is a VVER-1000 type pressurized water reactor, was determined. For the depletion and decay calculations, ORIGEN code was utilized. The results are presented for burnups of 30 to $49 \mathrm{GWd} / \mathrm{MTHM}$ and different cooling times up to 100 years. According to these results, total activity of a spent fuel assembly with initial enrichment of $3.92 \%$, burnup of $49 \mathrm{GWd} / \mathrm{MTHM}$, and cooling time of 3 years is $1.92 \times 10^{16} \mathrm{~Bq}$. The results can be utilized specifically in transportation/storage cask design for spent fuel management of Bushehr nuclear power plant.

\section{Introduction}

After removal from the reactor core, nuclear spent fuels are highly radioactive and rigorously radiation protection design shall be provided to ensure safety of workers, public, and environment during different operational stages such as handling, transportation, and storage of spent fuels. It is necessary to determine radioactive source specification of spent fuels before any radiation protection design.

Although many hundreds of fission product isotopes are formed in the nuclear reactor, most have very short half-lives and decay days to weeks after their creation. Generally, the radioactivity of the spent fuels caused mainly by the presence of fission products (e.g., ${ }^{131} \mathrm{I},{ }^{137} \mathrm{Cs}$, and ${ }^{90} \mathrm{Sr}$ ), activation products (e.g., ${ }^{60} \mathrm{Co}$ and ${ }^{63} \mathrm{Ni}$ ), and long-lived actinides (e.g., ${ }^{239} \mathrm{Pu},{ }^{237} \mathrm{~Np}$, and ${ }^{241} \mathrm{Am}$ ). The final composition of the spent fuels depends on different parameters such as the fuel type, chemical composition, level of initial enrichment in ${ }^{235} \mathrm{U}$, neutron energy spectrum of reactor, the fuel burnup, and cooling time [1].
In spite of the fact that there are different studies on determination of radioactive source specification of the spent fuels, a few works have been directed towards the VVER-1000 spent fuels in comparison with typical PWR ones [2-5]. On the other hand, the overall photon and neutron release rates are provided mostly without energy spectrum of released photons which is an important parameter in the radiation protection design.

In this study, radioactive source specification of a spent fuel assembly (SFA) of Bushehr nuclear power plant (BNPP) was evaluated. The BNPP is a VVER-1000 Russian type (model V-460) pressurized water reactor which has been in full commercial operation since 2013 [7]. The BNPP reactor will be loaded with 126 tons of about $4 \%$ enriched fuel having 3-year life cycle. Maximum burnup of the fuels is $49 \mathrm{GWd} / \mathrm{MTHM}$ (gigawatt day per metric tons of heavy metal). At the end of the useful life of fuels, the SFAs will be stored at least for 3 years inside the pool next to the core. The annual spent fuel production of the BNPP is about 21 tons of heavy metal. The main characteristics of BNPP fuel assembly (FA) are presented in Table 1 [8]. 
TABLE 1: Main characteristics of the FAs used in BNPP.

\begin{tabular}{lc}
\hline Parameter & Value \\
\hline Fuel assembly & \\
Reactor type & VVER-1000 (V-446) \\
Geometry & Hexahedral prism \\
Height, $\mathrm{m}$ & 4.570 \\
Fuel $\left(\mathrm{UO}_{2}\right.$ ) mass, $\mathrm{kg}$ & 489.8 \\
Fuel enrichment & \\
Assembly type 40 & \\
$\quad$ Average, ${ }^{235} \mathrm{U}$ wt $\%$ & 4.02 \\
$\quad$ Type $1,{ }^{235} \mathrm{U}$ wt $\%$ (number of rods) & $4.1(245)$ \\
$\quad$ Type $2,{ }^{235} \mathrm{U}$ wt $\%$ (number of rods) & $3.7(66)$ \\
Fuel rods & \\
Number of fuel rods & 311 \\
Clad inside diameter, mm & 7.73 \\
Clad outside diameter, mm & 9.1 \\
Clad material & Alloy $\mathrm{Zr}+1 \% \mathrm{Nb}$ \\
Active fuel length, $\mathrm{m}$ & 3.53 \\
\hline
\end{tabular}

\section{Depletion and Decay Calculation}

The rate of change in the amount of a specific isotope is equal to its production rate minus its removal rate. Consequently, a general expression for the formation and disappearance of a nuclide by nuclear transmutation and radioactive decay can be written as follows [9]:

$$
\begin{aligned}
\frac{\mathrm{d} X_{i}}{\mathrm{~d} t}= & \sum_{j=1}^{N} l_{i j} \lambda_{j} X_{j}+\varphi \sum_{k=1}^{N} f_{i k} \sigma_{k} X_{k}-\left(\lambda_{i}+\varphi \sigma_{i}+r_{i}\right) X_{i} \\
& +F_{i}, \quad i=1, \ldots, N,
\end{aligned}
$$

where $X_{i}$ is the atom density of nuclide $i, N$ is the number of nuclides, $l_{i j}$ is the fraction of radioactive disintegration by nuclide $j$ which leads to nuclide $i$ formation, $\lambda_{j}$ is the radioactive decay constant, $\varphi$ is the space and energy averaged neutron flux, $f_{i k}$ is the fraction of neutron absorption by nuclide $k$ which leads to formation of nuclide $i, \sigma_{k}$ is the spectrum averaged neutron absorption cross section of nuclide $k, r_{i}$ is the continuous removal rate of nuclide $i$ from the system, and $F_{i}$ is the continuous feed rate of nuclide $i$.

In case of no removal and no feed of nuclide $i$, such as spent fuels in the reactor core, (1) for $N$ nuclides is a homogeneous first-order ordinary differential equation system. To solve this system of equations and determine time dependent composition of BNPP SFA, ORIGEN2 code was utilized.

The ORIGEN is a widely used computer code for calculating the buildup and decay of radioactive materials. The code obtains data from the decay library regarding the halflives and decay branching fractions of the radionuclides. The code calculates the daughter of each nuclear decay or transformation and the rate at which the accumulation occurs. The ORIGEN code uses a matrix exponential method to solve a large system of coupled, linear, first-order ordinary differential equations with constant coefficients (1).
TABLE 2: The result of benchmark calculations of VVER-1000 SFA (60 GWd/MTHM and 3-year cooling time).

\begin{tabular}{lccc}
\hline & $\begin{array}{c}\text { Gamma emission } \\
(\mathrm{MeV} / \mathrm{s})\end{array}$ & $\begin{array}{c}\text { Neutron emission } \\
(\mathrm{n} / \mathrm{s})\end{array}$ & $\begin{array}{c}\text { Decay } \\
\text { heat }(\mathrm{kW})\end{array}$ \\
\hline $\begin{array}{l}\text { Ref. [6] } \\
\text { (averaged) }\end{array}$ & $6.55 \mathrm{E} 15$ & $6.11 \mathrm{E} 08$ & 2.42 \\
This study & $6.13 \mathrm{E} 15$ & $4.66 \mathrm{E} 08$ & 2.42 \\
\hline Uncertainty & $<6.5 \%$ & $<24 \%$ & $<1 \%$ \\
\hline
\end{tabular}

There are three sections of nuclides in the ORIGEN2 databases: 130 actinides, 850 fission products, and 720 activation products (a total of 1700 nuclides). These sections are formed by gathering the 1300 unique nuclides (300 stables) in the databases since some nuclides appear in more than one section. Although cross-sectional libraries for several reactor types such as typical PWR, BWR, and CANDU are provided, there is no specific library for VVER-1000 reactors in ORIGEN2 code. Recently, attempts to generate a crosssectional library for VVER-1000 type reactors is addressed [10]. To examine the capability of the ORIGEN2 libraries in prediction of VVER-1000 spent fuel specification, benchmark calculations were performed in this study.

\section{Results and Discussion}

To validate the results of ORIGEN2 calculations in this study and to examine the capability of the ORIGEN2 libraries in prediction of VVER-1000 spent fuel specification, calculational benchmark problems presented in $[3,6]$ were employed. In the calculational benchmark presented in $[3,6]$, different codes such as CARE, OREST-96, and ORIGENARP were utilized in source calculations. According to these benchmark problems, depletion and decay calculation for a VVER-1000 SFA with initial enrichment of $4.4 \%$ and burnup of $60 \mathrm{GWd} / \mathrm{MTHM}$ was carried out by use of ORIGEN2 code. The results of benchmark calculation are presented in Table 2.

The PWRU cross-sectional library was used for fuel depletion calculations presented in this article. The result of benchmark problems in this study differs from the averaged results presented in reference [6] by less than $6.5 \%$ for the gamma source, less than $24 \%$ for the neutron source, and less than $1 \%$ for decay heat. It is necessary to mention that the differences between results for the neutron source were far less than $24 \%$ in some cases (e.g., $13 \%$ in case of Russian results presented in [6]). Comparison of the results reveals that the typical PWR libraries of ORIGEN2 code are sufficient to determine the source specification of VVER-1000 spent fuels. On the other hand, the results are in acceptable range for radiation protection purposes. Generally, the differences between results mainly are caused by different data libraries as well as different methods used in different codes.

According to the BNPP FA characteristics and its irradiation history inside reactor core, depletion and decay calculations were carried out by use of the ORIGEN2 code. The results of these calculations for photon release rate and total activity of the SFA with initial enrichment of $3.92 \%$, burnup of $49 \mathrm{GWd} / \mathrm{MTHM}$, and cooling time of 1 to 100 years 
TABLE 3: Photon release rate and total activity of the BNPP SFA (49 GWd/MTHM).

\begin{tabular}{lcccc}
\hline Cooling time (years) & \multicolumn{2}{c}{$\begin{array}{c}\text { Photon release rate (photon/s) } \\
\text { Fission products }\end{array}$} & Total activity (Bq) \\
\hline At discharge & Actinides & $4.27 \mathrm{E} 18$ & $5.58 \mathrm{E} 18$ & $4.01 \mathrm{E} 18$ \\
1 & $1.31 \mathrm{E} 18$ & $4.29 \mathrm{E} 16$ & $4.29 \mathrm{E} 16$ & $4.76 \mathrm{E} 16$ \\
2 & $7.61 \mathrm{E} 13$ & $2.34 \mathrm{E} 16$ & $2.34 \mathrm{E} 16$ & $2.76 \mathrm{E} 16$ \\
3 & $4.53 \mathrm{E} 13$ & $1.49 \mathrm{E} 16$ & $8.49 \mathrm{E} 16$ & $1.92 \mathrm{E} 16$ \\
5 & $4.02 \mathrm{E} 13$ & $8.25 \mathrm{E} 15$ & $4.88 \mathrm{E} 15$ & $1.27 \mathrm{E} 16$ \\
10 & $4.17 \mathrm{E} 13$ & $4.83 \mathrm{E} 15$ & $3.45 \mathrm{E} 15$ & $8.97 \mathrm{E} 15$ \\
20 & $4.83 \mathrm{E} 13$ & $3.39 \mathrm{E} 15$ & $2.69 \mathrm{E} 15$ & $6.47 \mathrm{E} 15$ \\
30 & $5.71 \mathrm{E} 13$ & $2.62 \mathrm{E} 15$ & $1.68 \mathrm{E} 15$ & $4.93 \mathrm{E} 15$ \\
50 & $6.17 \mathrm{E} 13$ & $1.62 \mathrm{E} 15$ & $1.07 \mathrm{E} 15$ & $2.96 \mathrm{E} 15$ \\
70 & $6.44 \mathrm{E} 13$ & $1.01 \mathrm{E} 15$ & $5.58 \mathrm{E} 14$ & $1.84 \mathrm{E} 15$ \\
100 & $6.34 \mathrm{E} 13$ & $4.98 \mathrm{E} 14$ & & $9.54 \mathrm{E} 14$ \\
\hline
\end{tabular}

TABLE 4: Photon release rate of the BNPP SFA in 18 groups of energy (49 GWd/MTHM and 3-year cooling time).

\begin{tabular}{lcc}
\hline $\begin{array}{l}\text { Energy group } \\
\text { number }\end{array}$ & Average energy $(\mathrm{MeV})$ & $\begin{array}{c}\text { Photon release } \\
\text { rate (photon/s) }\end{array}$ \\
\hline 1 & 0.01 & $3.92 \mathrm{E} 15$ \\
2 & 0.025 & $9.08 \mathrm{E} 14$ \\
3 & 0.0375 & $9.37 \mathrm{E} 14$ \\
4 & 0.0575 & $7.99 \mathrm{E} 14$ \\
5 & 0.085 & $5.46 \mathrm{E} 14$ \\
6 & 0.125 & $5.93 \mathrm{E} 14$ \\
7 & 0.225 & $4.71 \mathrm{E} 14$ \\
8 & 0.375 & $2.70 \mathrm{E} 14$ \\
9 & 0.575 & $4.73 \mathrm{E} 15$ \\
10 & 0.85 & $1.45 \mathrm{E} 15$ \\
11 & 1.25 & $2.52 \mathrm{E} 14$ \\
12 & 1.75 & $1.24 \mathrm{E} 13$ \\
13 & 2.25 & $1.32 \mathrm{E} 13$ \\
14 & 2.75 & $3.14 \mathrm{E} 11$ \\
15 & 3.5 & $3.97 \mathrm{E} 10$ \\
16 & 5 & $1.06 \mathrm{E} 07$ \\
17 & 7 & $1.22 \mathrm{E} 06$ \\
18 & 9.5 & $1.40 \mathrm{E} 05$ \\
\hline & & $1.49 \mathrm{E} 16($ photon/s) \\
& & $4.8 \mathrm{E} 15(\mathrm{MeV} / \mathrm{s})$ \\
\hline
\end{tabular}

are presented in Table 3. It is necessary to mention that the contribution of activation products is very low and is not presented in this Table. As it is shown in Table 3, during the first 100 years after removal from the core, the photon release rate of the SFA mainly is caused by the fission products.

Another important parameter in any radiation protection design is the energy of the released radiations. The photon release rate of BNPP SFA with burnup of $49 \mathrm{GWd} / \mathrm{MTHM}$ and cooling time of 3 years is presented in Table 4 in 18 groups of energy.
TABle 5: Neutron sources of the BNPP SFA (3-year cooling time).

\begin{tabular}{|c|c|c|c|c|}
\hline \multirow{2}{*}{\multicolumn{2}{|c|}{$\begin{array}{c}\text { Burnup (GWd/MTHM) } \\
\text { Neutron sources }\end{array}$}} & 30 & 40 & 49 \\
\hline & & \multicolumn{3}{|c|}{ Neutron release rate $(\mathrm{n} / \mathrm{s})$} \\
\hline \multirow{12}{*}{$($ Alpha, $\mathrm{n})$ reaction } & ${ }^{235} \mathrm{U}$ & 6.03E00 & $4.08 \mathrm{E} 00$ & $2.76 \mathrm{E} 00$ \\
\hline & ${ }^{236} \mathrm{U}$ & $6.66 \mathrm{E} 01$ & 7.53E01 & 7.97E01 \\
\hline & ${ }^{238} \mathrm{U}$ & $4.89 \mathrm{E} 01$ & $4.86 \mathrm{E} 01$ & 4.83E01 \\
\hline & ${ }^{238} \mathrm{Pu}$ & $6.97 \mathrm{E} 05$ & $1.42 \mathrm{E} 06$ & $2.31 \mathrm{E} 06$ \\
\hline & ${ }^{239} \mathrm{Pu}$ & $1.05 \mathrm{E} 05$ & $1.11 \mathrm{E} 05$ & $1.13 \mathrm{E} 05$ \\
\hline & ${ }^{240} \mathrm{Pu}$ & $1.43 \mathrm{E} 05$ & $1.91 \mathrm{E} 05$ & 2.19E05 \\
\hline & ${ }^{241} \mathrm{Am}$ & $2.06 \mathrm{E} 05$ & $3.06 \mathrm{E} 05$ & $3.75 \mathrm{E} 05$ \\
\hline & ${ }^{243} \mathrm{Am}$ & $1.91 \mathrm{E} 03$ & $5.69 \mathrm{E} 03$ & $1.18 \mathrm{E} 04$ \\
\hline & ${ }^{242} \mathrm{Cm}$ & $1.20 \mathrm{E} 05$ & 2.37E05 & $4.21 \mathrm{E} 05$ \\
\hline & ${ }^{243} \mathrm{Cm}$ & $3.02 \mathrm{E} 03$ & $9.46 \mathrm{E} 03$ & 2.02E04 \\
\hline & ${ }^{244} \mathrm{Cm}$ & $1.60 \mathrm{E} 05$ & $7.02 \mathrm{E} 05$ & $1.96 \mathrm{E} 06$ \\
\hline & SUM & $1.44 E 06$ & $2.98 E 06$ & $5.43 E 06$ \\
\hline \multirow{9}{*}{ Spontaneous fission } & ${ }^{235} \mathrm{U}$ & $2.69 \mathrm{E} 00$ & $1.82 \mathrm{E} 00$ & $1.23 \mathrm{E} 00$ \\
\hline & ${ }^{238} \mathrm{U}$ & $5.87 \mathrm{E} 03$ & $5.83 \mathrm{E} 03$ & 5.79E03 \\
\hline & ${ }^{238} \mathrm{Pu}$ & $1.14 \mathrm{E} 05$ & $2.31 \mathrm{E} 05$ & 3.77E05 \\
\hline & ${ }^{240} \mathrm{Pu}$ & 7.54E05 & $1.01 \mathrm{E} 06$ & $1.15 \mathrm{E} 06$ \\
\hline & ${ }^{242} \mathrm{Pu}$ & $1.52 \mathrm{E} 05$ & $3.18 \mathrm{E} 05$ & 5.17E05 \\
\hline & ${ }^{242} \mathrm{Cm}$ & 5.82E05 & $1.15 \mathrm{E} 06$ & 2.04E06 \\
\hline & ${ }^{244} \mathrm{Cm}$ & $1.93 \mathrm{E} 07$ & $8.46 \mathrm{E} 07$ & $2.35 \mathrm{E} 08$ \\
\hline & ${ }^{246} \mathrm{Cm}$ & $3.35 \mathrm{E} 04$ & $2.90 \mathrm{E} 05$ & $1.29 \mathrm{E} 06$ \\
\hline & SUM & $2.09 E 07$ & $8.76 E 07$ & $2.41 E 08$ \\
\hline \multicolumn{2}{|l|}{ Total } & $2.24 E 07$ & $9.05 E 07$ & $2.46 E 08$ \\
\hline
\end{tabular}

In addition to the gamma emitter sources, there are two different neutron sources of (alpha, $n$ ) reaction and spontaneous fission in the spent fuels. These sources for BNPP SFA with initial enrichment of $3.92 \%$, burnups of 30 to $49 \mathrm{GWd} / \mathrm{MTHM}$, and cooling time of 3 years are presented in Table 5. The data in Table 5 declares that, with increase in burnup, the neutron emission of the BNPP SFA will increase. Moreover, the neutron emission of the BNPP SFA is dominantly from spontaneous fission of ${ }^{244} \mathrm{Cm}$, especially in higher burnups. The contribution of spontaneous fission of 
TABLE 6: The radioactive source specification and decay heat of the BNPP SFA (3-year cooling time).

\begin{tabular}{lcccc}
\hline \multirow{2}{*}{ Burnup (GWd/MTHM) } & \multicolumn{2}{c}{ Gamma emission } & Neutron emission $(\mathrm{n} / \mathrm{s})$ & Decay heat $(\mathrm{kW})$ \\
\hline 30 & $($ Photon/s) & $(\mathrm{MeV} / \mathrm{s})$ & $2.24 \mathrm{E} 07$ & 1.14 \\
40 & $9.11 \mathrm{E} 15$ & $2.46 \mathrm{E} 15$ & $9.05 \mathrm{E} 07$ & 1.49 \\
49 & $1.17 \mathrm{E} 16$ & $3.53 \mathrm{E} 15$ & $2.46 \mathrm{E} 08$ & 1.94 \\
\hline
\end{tabular}

${ }^{244} \mathrm{Cm}$ in burnup of 30 and $49 \mathrm{GWd} / \mathrm{MTHM}$ is about 86 and $95 \%$ of the total neutron emission, respectively.

Even after removal from the core and fission reactions have ceased, the fuel remains hot due to the decay heat from the highly radioactive fission products. According to the provided calculations, decay heat of the BNPP SFA with burnup of $49 \mathrm{GWd} / \mathrm{MTHM}$ and cooling time of 3 years is $1.94 \mathrm{~kW}$. The results of ORIGEN2 calculations for the radioactive source specification and decay heat of the BNPP SFA with initial enrichment of $3.92 \%$, cooling time of 3 years, and burnups of 30 to $49 \mathrm{GWd} / \mathrm{MTHM}$ are summarized in Table 6.

\section{Conclusion}

Radioactive source specifications of BNPP SFA were evaluated by use of ORIGEN2 depletion and decay calculation code. Benchmark calculations were provided to validate the results of ORIGEN2 calculations in this study. Comparison of the results of benchmark calculations in this study with other references revealed that utilization of the typical PWR libraries of ORIGEN2 code for BNPP fuels is acceptable, at least for radiation protection purposes. It is emphasized that for some calculations, such as burnup credit criticality calculations, in which more precise prediction of source specification is needed, the generation of cross-sectional library for VVER-1000 type reactor is unavoidable.

The calculated source specifications of BNPP SFA are presented for burnups of 30 to $49 \mathrm{GWd} / \mathrm{MTHM}$ and different cooling times up to 100 years. According to these results, total activity, neutron emission, and decay heat of BNPP SFA with initial enrichment of $3.92 \%$, burnup of 49 GWd/MTHM, and cooling time of 3 years are $1.92 \times 10^{16} \mathrm{~Bq}, 2.46 \times 10^{8} \mathrm{n} / \mathrm{s}$, and $1.94 \mathrm{~kW}$, respectively.

\section{Competing Interests}

The authors declare that there are no competing interests regarding the publication of this paper.

\section{References}

[1] R. C. Ewing, "Long-term storage of spent nuclear fuel," Nature Materials, vol. 14, no. 3, pp. 252-257, 2015.

[2] M. B. Emmett, "Calculational benchmark problems for VVER1000 mixed oxide fuel cycle," in Proceedings of the Topical Meeting on Radiation Protection for Our National Priorities, Washington, DC, USA, September 2000.

[3] A. G. Kalashnikov, V. I. Levanov, G. N. Mantourov et al., "Calculations in radiation characteristics of fresh and spent FA with uranium fuel and fuel on the basis of weapons-grade and civil plutonium of VVER-1000 reactor," in Proceedings of the International Conference Scientific Research on the Back-End of the Fuel Cycle for the 21 Century, pp. 1-4, Avignon, France, October 2000.

[4] I. I. Linge, E. F. Mitenkova, and N. V. Novikov, "End-to-end calculation of the radiation characteristics of VVER-1000 spent fuel assemblies," Physics of Atomic Nuclei, vol. 75, no. 13, pp. 1603-1615, 2012.

[5] P. Petrova, "Calculation of the neutron sources in the spent nuclear fuel from WWER-1000," BAS Transactions, vol. 61, 2008.

[6] M. B. Emmett, "Calculational benchmark problems for VVER1000 mixed oxide fuel cycle," ORNL/TM 1999/207, Oak Ridge National Laboratory, 1999.

[7] International Atomic Energy Agency, Nuclear Power Reactors in the World, vol. 2 of IAEA Reference Data Series, IAEA, Vienna, Austria, 2015.

[8] Design and Engineering Survey Institute, Safety Analysis Report for the Bushehr Nuclear Power Plant, Atomenergoproekt, Moscow, Russia, 2003.

[9] M. Zheng, W. Tian, H. Wei et al., "Development of a MCNPORIGEN burn-up calculation code system and its accuracy assessment," Annals of Nuclear Energy, vol. 63, pp. 491-498, 2014.

[10] K. Hadad, M. Nematolahi, and A. Golestani, "VVER-1000 cross-section library generation for ORIGEN-II based on MCNP calculations," International Journal of Hydrogen Energy, vol. 40, no. 44, pp. 15158-15163, 2015. 

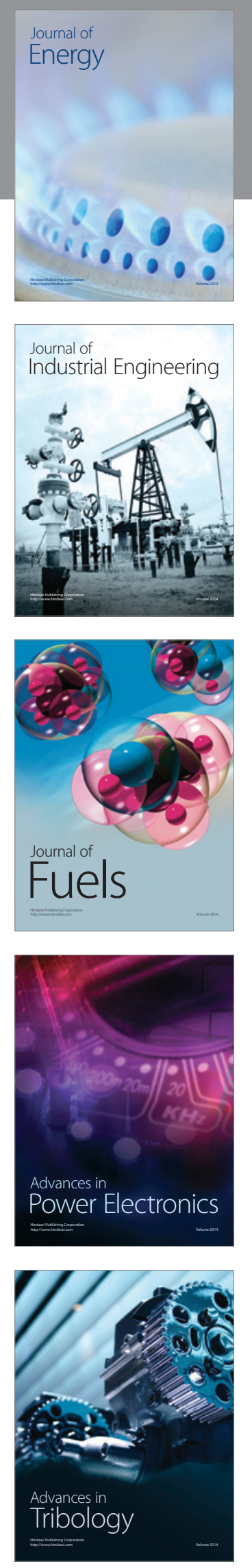
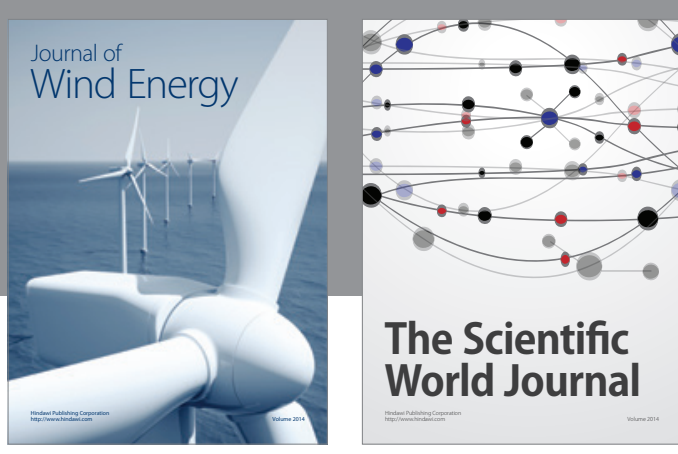

The Scientific World Journal
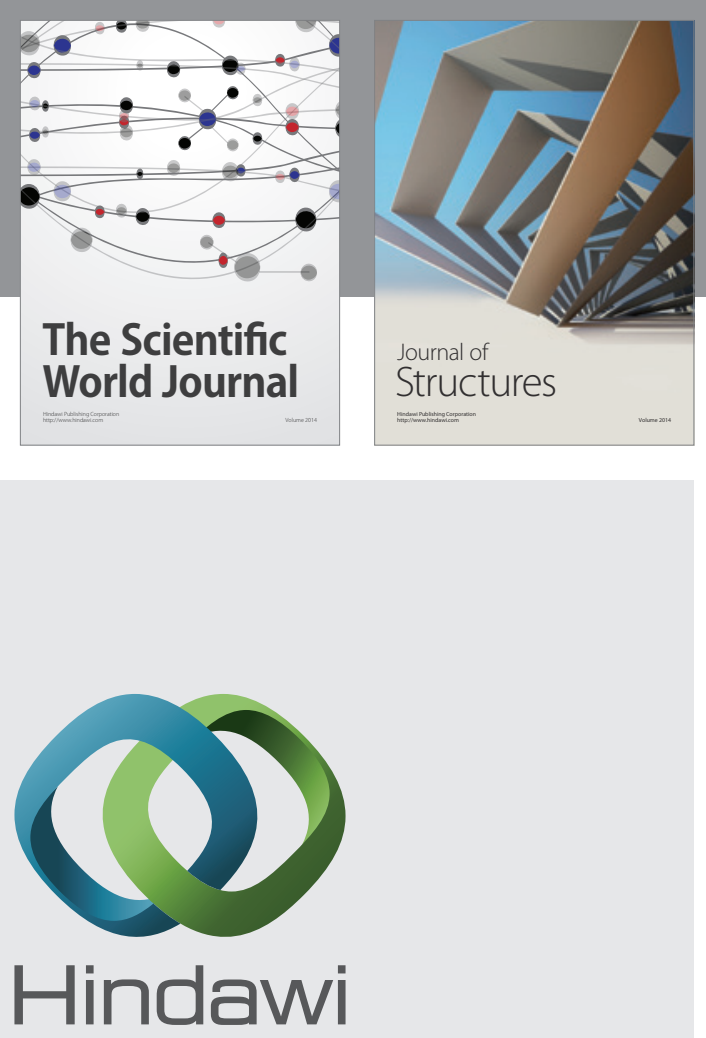

Submit your manuscripts at

http://www.hindawi.com
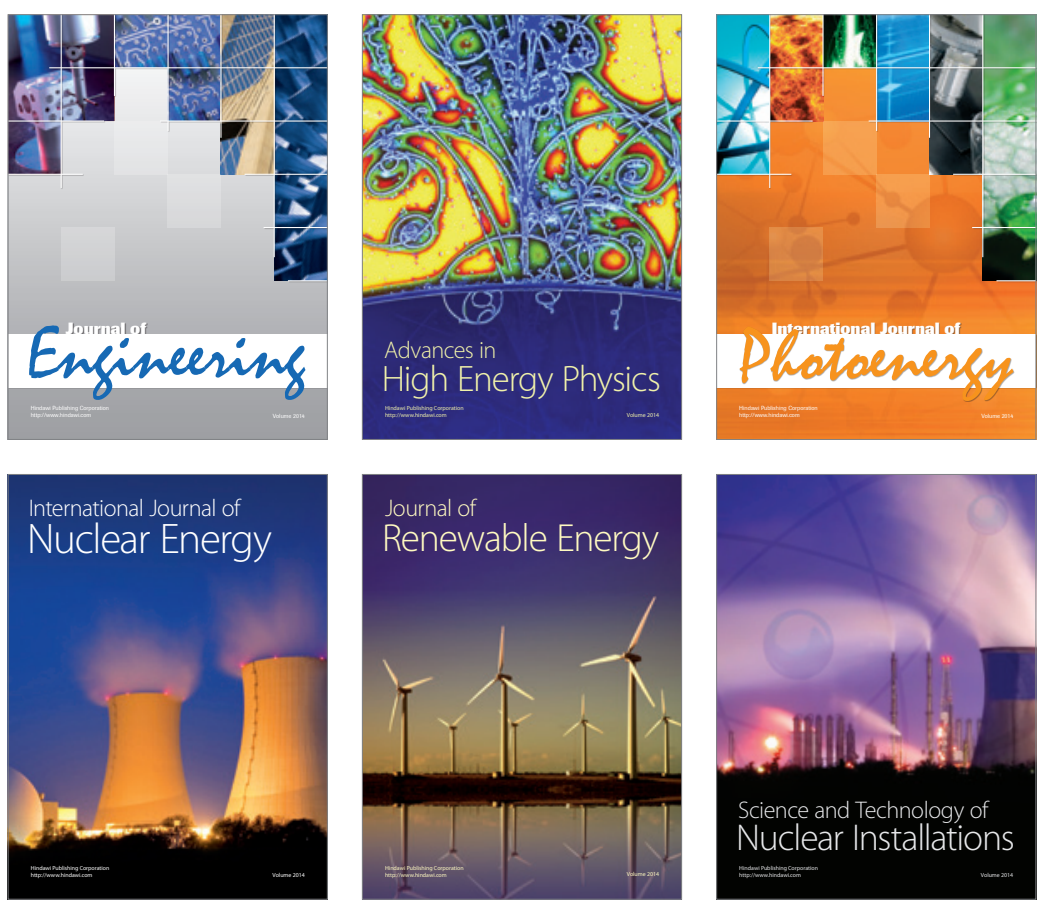
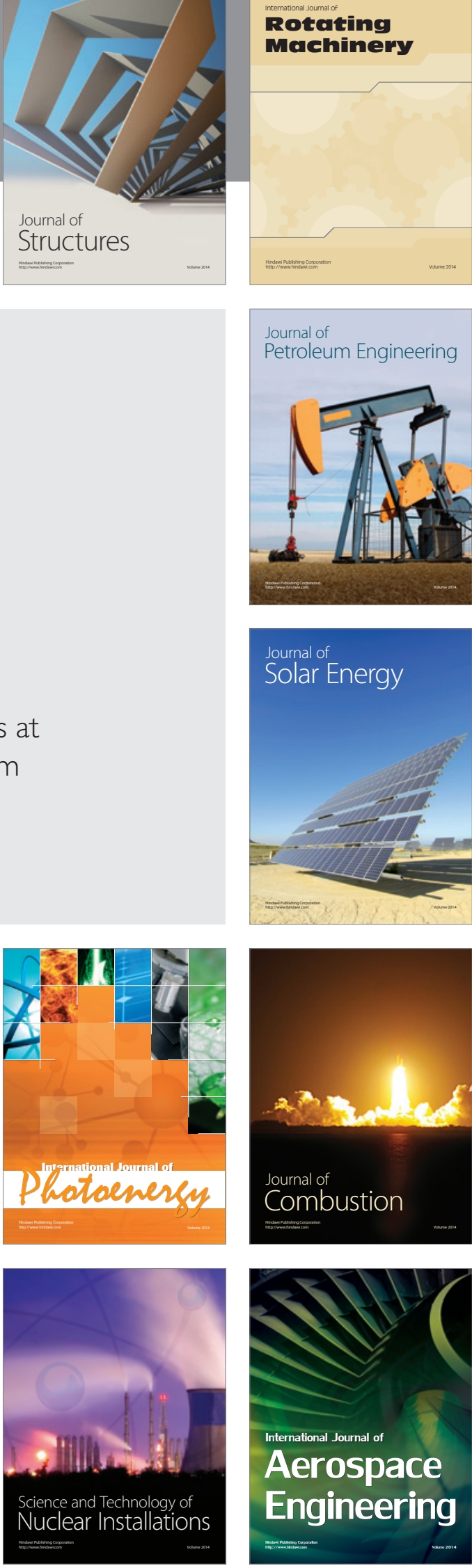